\title{
Late Holocene erosion in NW Anatolia from sediments of Lake Manyas, Lake Ulubat and the southern shelf of the Marmara Sea, Turkey
}

\author{
Kazanci N. ${ }^{1,2^{*}}$, Leroy S. ${ }^{3}$, Ileri Ö. ${ }^{2+}$, Emre Ö. ${ }^{4}$, Kibar M. ${ }^{5}$ and Öncel S. ${ }^{1}$ \\ 1 Gebze Institute of Technology, 41400 Gebze, Kocaeli, Turkey. Fax: +90-262-653 8490, e-mail: \\ nkazanci@penta.gyte.edu.tr,kazanci@eng.ankara.edu.tr \\ 2 Department of Geological Engineering, Faculty of Engineering, Ankara University 06100 Besevler, Ankara, Turkey \\ Fax: +90-312-215 0487, e-mail; ileri@eng.ankara.edu.tr. \\ 3 Department of Geography and Earth Sciences, Brunel University, Uxbridge, Middlesex UB8 3PH, (West London), \\ UK. Fax: +44-1895-203217, e-mail: Suzanne.Leroy@brunel.ac.uk. \\ 4 Geology Department of General Directorate of Mineral Research and Exploration, 06520, Ankara, Turkey. Fax: +90- \\ 312-2879188, e-mail: emre@mta.gov.tr. \\ 5 Soil Science Department of Faculty of Agriculture, Ankara University, 06110 Diskapi, Ankara, Turkey, e-mail: \\ mkibar@agri.ankara.edu.tr
}

\begin{abstract}
This paper deals with modern and ancient sedimentation in fresh water lakes and the marine shelf of the southern Marmara region, NW Anatolia, Turkey. Most of the information has been obtained from monitoring of suspended load discharged into two lakes (Manyas and Ulubat) in the last 45 years and from 8-11 m thick lacustrine sediments, in addition to radiocarbon-dated shelf sediments. This allows a holistic approach to the drainage basin denudation over time. The results show that the sedimentation rates in the lakes were low $0.22 \mathrm{~cm}_{\mathrm{yr}}{ }^{-1}$, from 4000-2000 $\mathrm{yr} \mathrm{BP}$ and then they increased $\left(0.29 \mathrm{~cm}_{\mathrm{yr}} \mathrm{yr}^{-1}\right)$ up to sub-recent times and reached $0.44 \mathrm{~cm} \cdot \mathrm{yr}^{-1}$ in the last century. It is suggested that deforestation created high rates of sedimentation in the basins and/or strong denudation of the region during the Late Holocene. This study also shows that for shallow freshwater lakes the calculation of sedimentation rates must include fine particles lost by the outlets and coarse-grained bed load deposited on their shores. In addition, a high rate of sedimentation has been created by short, but repetitive intense depositions. During the last century particularly during the last 45 years the rate of sedimentation or denudation has increased dramatically in NW Turkey. The two World Wars and mismanagement of the land had important local effects by increasing deforestation and resulting in the present erosive conditions.
\end{abstract}

\section{Keywords}

Sedimentation rate, denudation, Sea of Marmara, NW Anatolia, Ulubat, Manyas, Late Holocene,

- corresponding author

+Present address: Geology Department of General Directorate of Mineral Research and Exploration, 06520,

Ankara, Turkey. Fax: +90-312-2879188, e-mail: Ozden@mta.gov.tr. 


\section{Introduction}

In arid and semi-arid regions worldwide, lakes are one of the best sedimentary archives to reflect environmental changes over a variety of timescales (Eugster and Hardie, 1978; Fritz, 1996; Luque and Julià, 2002); because the clastic fraction of fresh-water lacustrine sediment generally derives from the drainage basin by erosion that may be the product of natural and/or anthropogenic forcing mechanisms. A a satisfactory estimate of the relationship between climate, the amount of erosion and sedimentation rates is however not available yet (Einsele and Hinderer, 1998; Verschuren, 1999). Population increase, intensive farming, land mismanagement and consequent deforestation are the predominant factors influencing the rate of erosion (Morgan, 1986; Lasanta et al., 2000). Erosion and/or denudation is also one of the main surface sedimentary process in Turkey both because of its semi-arid Mediterranean or continental climate and because of its strong relief reaching up to $4000 \mathrm{~m}$. Nearly $30 \%$ of the modern clastic deposit of the Black Sea has been

provided by Turkish rivers (Hay, 1994). Regular measurements during the last two decades show that c. $5,108.10^{3} \mathrm{~m}^{3}$ of suspended sediment have been annually transported to the seas (EIE, 2000). The real erosion in Anatolia must be higher than this since there are many small and large dams on rivers. The southern Marmara region appears to be a convenient area for comparison of sedimentation and erosion with the characteristics of a drainage basin (Fig. 1).

It is generally accepted that erosion and/or denudation in an area is a function of climate (via intensity of vegetation cover), erodibility of source rocks in the drainage basin and relief of the watershed catchment (Hurst, 1950; Chorley et al., 1984; Morgan, 1986). Since source rocks remain the same at least for a few millennia, the tectonic effect on relief is insignificant and anthropogenic activity is limited, sediment productivity of a drainage basin will solely be dependent on climate and/or presence of vegetation cover (Leopold et al., 1995). This approach to erosion however ignores enlargement of the drainage basin and change of marine base-level. The lakes of the southern Marmara region, particularly Lake Manyas and Lake Ulubat of the Late Holocene, provide a unique opportunity to see the roles of different factors on erosion or sedimentation because they collect sediments derived from different basins, their geological and geographical backgrounds are well known and their outlets form a river which enters the sea (Figs 1, 2). EIEI sediment observatories (Stations no 314, 317 (this one is on the outlet) and 302) have collected data on sediment load entering and leaving the lakes, water discharges and lake-level oscillations since 1960, and also $10.8 \mathrm{~m}-$ and $7.8 \mathrm{~m}-$ long sediment cores are available from lakes Manyas and Ulubat respectively. Moreover, many gravity cores in the southern shelf of the Marmara Sea, together with sediment data about rivers discharging onto the same shelf, could 
yield data to compare marine and lacustrine sedimentations, rates of deposition and lithologies as the same drainage basin provides sediments to the lakes and to the Marmara Sea (Fig. 1).

The rationale of this paper is to make use of the unique availability in north western Anatolia of both long-term modern sediment transportation (= erosion) monitoring data and late Holocene lacustrine sedimentation rates using recent and past sediment in Lake Manyas (as well as L. Ulubat and the Marmara Sea shelf) and its watershed catchment (Fig. 1) in order to obtain a holistic model for the reconstruction of denudation rates. Such data on erosion are urgently needed as all water bodies (reservoirs, natural and artificial lakes) are threatened and suffer from rapid siltation.

\section{Background}

\subsection{Geological and geographical background}

North western Anatolia, including the study area (Fig. 1), is a seismically active part of Turkey. The Marmara Sea, the Çanakkale strait (Dardanelles), the Istanbul strait (Bosphorous) and the North Anatolian Fault are the main geographic and tectonic elements of the region (Figs 1 \& 2). The Marmara Sea, which has a depth of $1271 \mathrm{~m}$ and surface area of $75 \times 210 \mathrm{~km}$ presently, was a lake during the late Pleistocene. In the early Holocene, the level of the Mediterranean Sea steadily rose until it reached the height of the Dardanelle sill $(-75 \mathrm{~m})$ and the Marmara trough became an inland sea. Rising sea level continued and met with the fresh water of the Black Sea when the water level passed over the Bosphorous sill (-32 m). The connections to the Black Sea and the Mediterranean Sea have strongly affected the hydrology, drainage and morphology of the region as the local and regional water base level increased drastically. Combined with tectonics, this increase of the base level gave rise to the modern hydrography of river courses and lakes, including Manyas and Ulubat (Fig. 3). The timing of the first post-glacial two-way exchange between the Black Sea and the Aegean Sea is debatable (Görür et al., 2001). It either occurred at 9,000 year BP (Aksu et al., 1999), at 7,150 yr BP (Ryan et al., 1997) or at 4,400 yr BP (Algan et al., 2001), depending on different hypotheses largely erected on the results of seismic profiles from either the Sea of Marmara or the Black Sea.

Lake Manyas, an important part of the study area, is located on the western side of a large W-E tectonic depression formed at the transition of the transform North Anatolian Fault (NAF) zone and the extensional tectonic regime of western Anatolia (Emre et al., 1997a). This depression (Manyas-Karacabey depression) is tilted towards the east where Lake Ulubat ( $2 \mathrm{~m}$ asl and a surface area of $138 \mathrm{~km}^{2}$ ) is located. Lake Ulubat controls the drainage of the whole southern Marmara region, i. e. up to ca $27,500 \mathrm{~km}^{2}$, called the Susurluk drainage basin. Some places in this basin have been 
strongly affected by karstic processes during the Neogene creating local lower areas (Emre et al., 1997b). The Susurluk basin is connected to the Marmara Sea by only one passage, the Karacabey gorge, at the end of which the modern, wave-dominated Kocasu delta has formed (Figs 1 and 2). The Kocasu delta has a subaerial plain of $48 \mathrm{~km}^{2}$ together with a progradation of $4 \mathrm{~km}$. This delta is the main sediment source for the southeastern shelf of the Marmara Sea, despite the upstream trapping of sediment by lakes (Kazanc1 et al., 1999).

The drainage area of Lake Manyas, ca $3022 \mathrm{~km}^{2}$, is an isolated, small part of the Susurluk drainage basin. The highest relief around the lake is $620 \mathrm{~m}$ and the elevation of c. three quarters of the drainage area is between $50-125$ $\mathrm{m} .2309 \mathrm{~km}^{2}$ of the whole sub-basin is drained by the Kocaçay River (162 km long). The topographic dip and average elevation of this river is $0.76 \%$ and $85 \mathrm{~m}$ respectively along its longitudinal section (Fig. 1).

In spite of a complex stratigraphy and various exposed rocks in the large Susurluk drainage basin (Yilmaz et al., 1990; Okay et al., 1991), the geology of Lake Manyas drainage area is relatively simple. Volcanics, clastic sedimentary rocks, clayey limestones and evaporites of Late Tertiary age and, to a lesser extent, metamorphic rocks are exposed in the relatively higher parts of this subbasin. However, collated borehole data have established that the lake is surrounded by large areas of Holocene alluvial deposits and also by some Pleistocene fluviatiles in the lower parts of the drainage basin (Kazancı et al., 1997). Some small, ephemeral streams (i.e. Sığırcıdere, Eğridere, Köydere, Ağadere) drain the lower areas and/or the plains, particularly north of the lake (Fig. 2A). Intensive cover of fresh aquatic and semi-aquatic plants at their mouths indicates that the clastic sediment loading from these lower areas to the lake is very low and so plants could grow. Lake Ulubat however is closely surrounded by karstified limestones of Mesozoic age in the east, sedimentary and volcani-sedimentary rocks of Neogene, mostly Miocene in age, form extensive units in the drainage area. These rocks provide a relatively low topography that has been incised by many medium-deep valleys. The highly elevated parts and the far southern part of the drainage basin comprise very compacted pre-Neogene rocks where river courses form a nearly rectangular drainage pattern as they generally follow fault lines (Fig. 1B). Loose and sanddominated alluvial deposits of latest Pleistocene-Holocene age formed in the western side of Lake Ulubat with thicknesses up 40 m, just south of Mustafakemalpaşa town (Emre et al., 1997b).

The origin of the modern lakes is still relatively uncertain, but it is thought that they began through channel damming of a meandering stream system, possibly during a period of late Holocene sea level increase (Emre et al., 1999). This increase caused a rise in base level and led to the formation of a series of deltas (Rivers Kocasu, Gönen and Biga Deltas) along the southern coast of the Sea of Marmara (Emre et al., 1997a; b) (Fig. 1 B). Boreholes in the surrounding areas have reached a Late Pleistocene, strongly oxidised alluvial sediment at depths of 10-12 m; the upper 
part of these sequences have a fluvial origin, mostly as flood plain deposits. Recent studies have shown that the late Quaternary evolution of the southern Marmara region has been controlled by sea-level oscillations (Emre et al., 1997a). In the Sea of Marmara, the deltaic plains (R. Gönen and Kocasu) have a step-like morphology, with the oldest terraces at $+6 \mathrm{~m}$ asl and the youngest ones at $+0.5 \mathrm{~m}$. In addition, a submarine terrace on the prodelta of the R. Kocasu has been detected at $15 \mathrm{~m}$ bsl. Emre et al. (1999) have compiled sea-level changes for the last 7,500 yr, based on ${ }^{14} \mathrm{C}$ data from boreholes in the modern R. Sakarya Delta in the Black Sea and correlations with present-day coastal morphology of the Marmara and Black Seas. The R. Sakarya delta is located at c. $140 \mathrm{~km}$ east of the Bosphorous strait. These authors suggest that sea level dropped sharply to $12 \mathrm{~m}$ bsl about 4,000 yr ago, then increased to $+4 \mathrm{~m}$, with the present sea level being attained 3,000-2,800 yr ago, probably under the control of Marmara-wide regional tectonics. Whether this oscillation is local or global remains unclear. Emre et al. (1997b) suggest that the southern Marmara lakes (such as Manyas and Ulubat) acquired their modern form in the last sea-level rise by channel damming (Fig. 3).

\subsection{Local and regional climate}

The dominant climate of the Susurluk basin is continental; the local topography and the distance from the sea are however a source of climatic diversity. The long-term average of precipitation in Figure 4 was compiled from data from eight meteorological stations in the basin (Erdoğan, 1988; Koçman, 1993). It shows that a range of $600-800 \mathrm{~mm}$ is found in the southern Marmara region (Fig. 4). Based on a 60 year-long record from the nearest meteorological station (Bandirma; on the Sea of Marmara coast, Figs 1 and 4) to Lake Manyas and its drainage basin, annual mean temperatures are $14{ }^{\circ} \mathrm{C}$, with mean July temperatures of $23.4{ }^{\circ} \mathrm{C}$ and mean January temperatures of $5.3{ }^{\circ} \mathrm{C}$. Annual mean precipitation is $706 \mathrm{~mm}$ with a December mean of $120.3 \mathrm{~mm}$ and an August mean of $13 \mathrm{~mm}$ (Table 1). Storms mainly occur in winter. North-easterly cool winds have a much greater effect upon the regional weather than do southwesterly mild winds (Erdoğan, 1988; Koçman, 1993; Özdemir and Kırmızıgül, 1997).

The potential vegetation in the area is Euxinian forest, near the limits of the Mediterranean woodland climax (Beug, 1967; Zohary, 1973). At present, the region is very open and intensively farmed. However some forested areas form patches on hills above an altitude of $500 \mathrm{~m}$ combined with cultivated plants (Bottema et al., 2001).

\section{3. Lake Manyas}

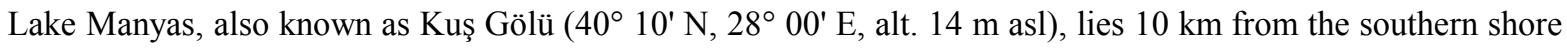
of the Sea of Marmara (Fig. 1). This shallow, open and eutrophic freshwater lake (20 km W-E by $14 \mathrm{~km} \mathrm{N-S)} \mathrm{has} \mathrm{a}$ 
maximum water depth of $4 \mathrm{~m}$, an average depth of only 1 to $2 \mathrm{~m}$ and a water surface of c. $150 \mathrm{~km}^{2}$ (Fig. $2 \mathrm{~A}$ ). The drainage area of L. Manyas is 3,022 $\mathrm{km}^{2}$ with the Kocaçay River (162 km long) as the main stream. In addition, the same river provides nearly all the sediment loading to the lake. According to measurements made between 1971 and 1999, the R. Kocaçay carries 293 T of suspended sediments per day (EIE, 2000), building up a relatively large delta on the southern lake shore. Lake levels fluctuate seasonally by up to $150 \mathrm{~cm}$, with a maximum in winter; however, the lake outlet has been regulated against excessive fluctuations since 1995 (Fig. 4). Lake water is used for the irrigation of the Karacabey plain; and the water quality has been reduced by infilling and chemical discharges. Several scientists have expressed concern for the ecological status of the lake (Altınsaçlı \& Griffiths, 2001; Arçak et al., 2000) and the need for urgent protective measures.

Recent studies (Kazanc1 et al., 1997; Suliman, 1998) have shown that not only the modern lake bottom but also the shores, typically the south-western shore occupied by the Kocaçay river delta, are covered by very fine-grained sediments. These are largely due to lake-bottom disturbance caused by north-easterly winds; as the lake is shallow, even moderate winds can influence the bottom. This is clearly seen by the temporary modification of the limpidity and the water colour from transparent to light grey and the decrease of Secchi-disc depth from 75-100 cm down to 5-10 cm on windy days (Kazanc1 et al., 1997). During major windstorms, the entire bottom surface sediment has been re-suspended and then pushed by waves towards the shore. Onshore, reeds and other aquatic plants act as a trap, providing a low energy environment for sediment deposition with organic matter. Furthermore, wind and/or water activity also prevents the preservation of large amounts of organic matter in the lake bottom except for some places which are heavily covered by plants. The Secchi-disc depth may reach $100 \mathrm{~cm}$ on sunny and mild days, but is often as low as $10 \mathrm{~cm}$. Present-day coastal deposition is mainly seen as a muddy delta in the south, prograding at a rate of $8-10 \mathrm{~cm} \mathrm{yr}^{-1}$. Aquatic $\mathrm{pH}$ varies intra-annually between 7.3-8.9, possibly due both to effluent from poultry mass production units in the north and to pesticides and fertilisers inwashed from farmland (EIE, 1993; Kazancı et al., 1997; Arçak et al., 2000).

\subsection{Lake Ulubat}

Lake Ulubat at the eastern end of the Manyas-Karacabey depression has a surface area of c. $138 \mathrm{~km}^{2}$ with a maximum water depth of $2.50 \mathrm{~m}$ (Fig. 2B). The average water depth is $1-1.50 \mathrm{~m}$. The annual fluctuations of the water level have been controlled since 1990 (Kazanc1 et al., 1998). The water surface of the lake is only $2 \mathrm{~m}$ above sea level, however the distance is c. $23 \mathrm{~km}$ from the Marmara Sea along the lake's outlet (via the Karacabey gorge). It is an open, eutrophic freshwater lake with an elongated shape (23 km E-W long and $12 \mathrm{~km} \mathrm{~N}-\mathrm{S}$ wide). Its periphery is irregular 
owing to fault scarps in the SE, old karstic features in the NE and delta progradation in the SW. Four islands of Mesozoic limestones delineate sub-basins in the lake that may influence water and sediment circulations. Other islands consist of sediment deposited after the formation of the lake. These islands become smaller or larger depending on seasonal water-level fluctuations (Fig. 2B).

The main water and sediment sources of Lake Ulubat are the River Mustafakemalpaşa (MKP) that has a drainage area of c. $10,414 \mathrm{~km}^{2}$. The delta of this river rapidly progrades into the lake on the SW shores. The delta has shifted towards the southeast probably under tectonic control (Fig. 2). The suspended sediment load of the river MKP has been about $1,258,143$ ton. $\mathrm{yr}^{-1}$ in the last 30 years (Table 4).

Water quality is poor due to discharges of factory wastewater and pesticides from agricultural runoff. These cause an increase in aquatic plants, so intensive that algal blooms have now become a common feature of the lake. In the $\mathrm{SE}$, the aquatic $\mathrm{pH}$ is 7.5 - 9 (intra-annual variation), most probably caused by additional water from springs from faulted Mesozoic limestones, however it decreases to 6.1-7.4 near the deltaic shores. Maximum Secchi-disc depths are around 50-75 $\mathrm{cm}$ on sunny days of early August from observations at 36 stations distributed in the whole lake area(Kazancı et al., 1998). Modern lake sediments are generally clayey silt with a very small volume of sand-size grains (2-9\%), in spite of clay dominance in some places. They are typically composed of feldspar, quartz, calcite, micas, smectite, illite and chlorite. This mineral paragenesis is very similar to that of Lake Manyas, probably as their drainage area is shared.

\subsection{The southern shelf of the Marmara Sea}

The Marmara Sea is a c. $210 \mathrm{~km}$-long and $75 \mathrm{~km}$-wide intercontinental sea between the Mediterranean and the Black Seas (Fig. 1). Its geological importance is not only a waterway between two seas, but also its two sills: Istanbul Boğazı (Bosphorous) and Çanakkale Boğazı (Dardanelles) at $-32 \mathrm{~m}$ and $-75 \mathrm{~m}$ depths respectively. These sills transform the Marmara and Black Seas into lakes when water level drops below these depths as seen many times in its geological history (Ryan et al., 1997, Aksu et al., 1999). The shelf area is relatively broad in the south and narrow in the north with a break at depth of c. $-110 \mathrm{~m}$ (Fig. 1B). The main cause of this asymmetry is tectonics that has generated a step-like, morphology enlarging toward the south by many oblique faults (Emre et al., 1997 a, b). These low water levels are also confirmed by the presence of old sandy beach deposits covered by modern sediments in the southern inner shelf (Ergin et al., 1997). 
The coastlines in the south are generally erosive and have formed cliffs. They are composed of pre-Neogene, mostly metamorphic, rocks. They form peninsulas, islands and bays. Modern deposition occurs only in deltas, the largest ones being the Kocasu, Gönen and Biga river deltas. The recent sediments with a rich marine fauna are mostly silty mud derived and transported from the southern drainage area. The correlation of sapropel layers within these deposits indicates that the present-day double-layered water stratification of the Marmara Sea has formed the sapropels and has occurred since at least the late Pleistocene (Çağatay et al., 1999).

\section{Data acquisition and analytical methods}

Water discharge and suspended sediment load, to the southern shelf of the Marmara Sea and also to lakes Manyas and Ulubat, have been measured by separate river observatories since 1952 (Fig. 1). Station 314 is on the River Kocacay, $6 \mathrm{~km}$ from L. Manyas and at $25 \mathrm{~m}$ above sea level, and Station 302 on the River Mustafakemalpaşa is $21 \mathrm{~km}$, from L. Ulubat and $40 \mathrm{~m}$ asl. Station 321 on the River Nilüfer was closed in 1985 as a high volume of waste water from Bursa town began to discharge into the river. Other stations are shown on Fig. 1. These data are provided by a longterm monitoring programme of the Electricity Management Office (EIEI). Data, such as annual sediment load, denudation rate and bed load, are calculated by the present authors using these original measurements. Table 2 provides details for the Kocaçay River, and monthly water discharge and suspended sediment transportation by River Kocaçay are summarized in Table 3. According to the data collection method used at the station, sediment samples were taken from flowing water near the bottom, so sand-size grains could be collected as suspended load when debit was high or water flow was fast and turbulent. Hence, it should be noted that suspended load here is not composed of pure clay- and silt-size particles and also it does not show the total sediment load transported. In order to calculate the total sediment load transported by any river, 10 to $50 \%$ of suspended load is added to values provided by the station according to the discharge characteristics of each river (EIE, 2000, p. 2). The value to be added is $35 \%$ of suspended sediment for streams in the Susurluk basin. This allows an estimation of the total sediment load transported by the Kocaçay River using the discharge pattern. It must be noted that measurements of water discharge and sediment load are made once a month but not on the same day of the month. Comparisons of precipitation, discharge and sediment load display a good correlation with lake level fluctuations and also with wet months of the continental area at the border with the Mediterranean one (Tables 1 - 3; Fig. 5). Table 4 is a summary of water and sediment load carried by the largest rivers of the southern Marmara region.

Some of the limnological characteristics of Lake Manyas and Lake Ulubat were surveyed in 1996 and 1997 respectively. Modern sediment samples taken by an Eckman grab from 32 and 34 localities of the lake bottoms were 
examined by routine sedimentological methods. Grain size and mineralogy of modern sediments at different sites are more or less uniform; however clay size particles are abundant near the shores because of reed cover and wind effect (Kazanc1 et al., 1997; 1998). In 1998, a coring campaign, using a hand-pushed Livingstone piston corer operated from a raft, retrieved a series of $5 \mathrm{~cm}$-diameter sediment cores, in $1 \mathrm{~m}$ sections with core labels ML (initials of Manyas Lake) at three sites and the longest core which reached to $10.8 \mathrm{~m}$ depth is at the centre of Lake Manyas (this coring technique does not preserve the thin fluid water-sediment interface) (Fig. 2A). Sediment concentrations in ${ }^{137} \mathrm{Cs},{ }^{210} \mathrm{~Pb}$, ${ }^{214} \mathrm{~Pb}$ and ${ }^{214} \mathrm{Bi}$ to be used for age interpretation were determined in homogenised sub-samples using high-resolution gamma spectrometry employing a germanium well-type detector (see Leroy et al., 2002 for detail). Some levels were dated by AMS ${ }^{14} \mathrm{C}$ method. Loss-on-Ignition data were obtained by the combustion of $5 \mathrm{~cm}^{3}$ sediment samples in a furnace at $550{ }^{\circ} \mathrm{C}$ and $950{ }^{\circ} \mathrm{C}$. The mineralogy of the sediment is based on optical, XRD and XRF analyses. Grain size analysis has been obtained by an automatic grain-size analyser with laser (Malvern Instruments, Mastersizer 2000 model). Sieving for macrofossils (such as seeds and shells) from $75-125 \mathrm{ml}$ sediment samples was achieved through 500 , 125 and $63 \mu \mathrm{m}$ mesh sieves after soaking in sodium pyrophosphate. Density, plasticity and porosity of bulk sediments were found by routine methods.

Lake Ulubat was cored in 2002 and a 7.8 m-long core was obtained using the same coring method as for L. Manyas (see above) but analyses of the sediments have not yet been completed. LOI has been obtained on the top 75 $\mathrm{cm}$ of core from the south-east of the lake (core AK02PVC4-1). The age data about this lake is from the literature (Bottema et al., 2001), from a core taken in 1988 on the southwestern shores. Sedimentary characteristics and ${ }^{14} \mathrm{C}$ dates on the cores of southern shelf of Marmara Sea have been taken from Çağatay et al. (2000).

\section{Results}

\subsection{Annual clastic load to lakes and to the Marmara Sea}

The detrital fraction of L. Manyas sediment is mainly transported by the River Kocaçay from a drainage area of $2308 \mathrm{~km}^{2}$. The inflow discharges into the lake forming a relatively large delta at its southern margin (Fig. 2A). This delta proves that the lake receives a large amount of coarse-grained bed load, although the Kayaca observatory on R. Kocaçay measures only suspended sediment transported to the lake. Data obtained from monthly records by the EIE (2000) show annual maxima, means and minima of discharge, sediment concentration and suspended sediment load (Table 2). To estimate sediment load as ton/day $\left(\mathrm{T} . \mathrm{d}^{-1}\right)$, a simple equation

$$
\text { Qs }=\text { Qw . C. } 0.0864
$$


is used. Here Qs = sediment load $\left(T \cdot \mathrm{d}^{-1}\right), \mathrm{Qw}=\operatorname{discharge}\left(\mathrm{m}^{3} \mathrm{~s}^{-1}\right), \mathrm{C}=$ concentration $(\mathrm{ppm}) .$. Also, the measurement method of the station (EIE, 2000) indicates that the relation between discharge and daily sediment load is

$$
\log \mathrm{Qs}=\mathrm{a}+\mathrm{b} \log \mathrm{Qw}
$$

or

$$
\text { Qs= 10.a } \cdot \text { Qw.b }
$$

When plotting the River Kocaçay records, discharge versus daily sediment load, a correlation line of Qs $=3.4566$ Qw1.373 is obtained with $\mathrm{R}^{2}=0.8631$ (EIE, 2000). By using the average water discharge for 26 years $\left(25.2 \mathrm{~m}^{3} \mathrm{~s}^{-1}\right)$ and formulae 1 and 3, it can be estimated that River Kocaçay transports 106,653 tons of suspended load to Lake Manyas each year.

In a year, Lake Manyas receives its maximum sediment load from December to April (Table 3). In summer, particularly from July to September, water discharge is lower than $2 \mathrm{~m}^{3} \mathrm{~s}^{-1}$ and so sediment load is hardly in evidence except for sporadic floods. This is to be expected under the present type of climate (Table 1 and 3).

Besides the drainage area of the River Kocaçay, the rest of the drainage basin of Lake Manyas is relatively flat with an average elevation of 25-35 m. These other rivers also contribute to the sediment trap. Hence, it may be estimated that only one tenth of the suspended sediment is transported out of the lake by the R. Kocaçay.

The annual sediment loads transported to Lake Ulubat and to the southern shelf of the Marmara Sea by other rivers (Fig. 1) for an average of 33 years are shown in Table 4. Results there were obtained by using formulae 1-3. The Mustafakemalpaşa River transports $1,258,143$ tons. $\mathrm{yr}^{-1}$ of suspended sediment to Lake Ulubat building a large delta, similar to the one in Lake Manyas, at the Kocadere River mouth. The outlets of the two lakes and the Simav River meet $4 \mathrm{~km}$ north of Karacabey town and form the Kocasu River flowing to the marine shelf (Fig. 1). Observatory 317 on this river measures suspended sediment of 464,950 tons.yr ${ }^{-1}$ (Table 4). When subtracting the Simav River sediment $\left(372,369\right.$ tons. $\left.\mathrm{yr}^{-1}\right)$ from this value, it is found that ca 92,580 tons. $\mathrm{yr}^{-1}$ are provided by the outlets but it is uncertain how much of it comes from which outlet. However, it is known that the majority of the suspended sediment and also the whole bed load provided by rivers, except for the Simav River which discharges directly to the sea, are trapped in lakes.

The total fluvial suspended sediment load transported to the Marmara Sea from NW Anatolian drainage areas is uncertain due to the lack of observatories on many moderate and small size rivers, most of which are seasonal. In our estimation, it is not below $2.5 .10^{6} \mathrm{~T}_{\mathrm{yr}}{ }^{-1}$ based on taking into consideration the unobserved rivers.

\subsection{Modern sediment of lake bottom surfaces}


The bottom surface of Lake Manyas is predominantly covered by silty mud and/or clayey silt according to the grain-size analysis of thirty-two samples distributed over the whole lake area (Kazanc1 et al., 1997). Additionally, some patchy beaches of 4 to $10 \mathrm{~m}$ can be observed on the western shores. These are not real beaches formed by wave action transporting coarse-grained sediments, but rather the sandy gravel here has been generated by wave erosion of coastal cliffs. Apart from these, sand and coarser grains are only seen at the mouth bars of the Kocaçay River.

The lake bottom mud has a bluish black and sometimes greenish grey colour because of the presence of organic matter with a volume from 3 to $12 \%$. The organic matter is relatively abundant at shallow shores where bottom surfaces are covered by aquatic plants. Volumetric ratio of silt and clay-size particles is 35 to $85 \%$ and 20 to $60 \%$ respectively. It should be noted that some parts of the lake bottom, particularly in the west-southwest, are hardened or compacted most probably owing to the loading effect of waves. As there is a lack of sedimentation, this may be compared with hardgrounds in stratigraphic records. No samples in these parts could be obtained.

The mineralogical composition of the silt-size grains of the lake mud mainly consists of quartz (35-85\%), feldspar (10-35\%) and calcite (10-30\%). The latter derives dominantly from fragmentation of old and young carbonate shells (Suliman, 1998). Clay-size particles are mainly composed of smectite (57-98\%), kaolinite (6-28\%) and, to a lesser extent, illite (3-20\%). Such a simple grain composition within the lake sediment is common as clay mineral paragenesis since the Neogene in the whole southern Marmara region is mainly characterized by smectite, illite, kaolinite and chlorite (Bayhan et al., 1997). Chemical analyses of modern lake sediments by XRF with a detection limit of $5 \%$ are correspond well with the mineralogy and the major element compositions of the older sediment (Holocene) of Lake Manyas (Table 5). Volume weight or bulk density of lacustrine sediment changes from $1.260 \mathrm{~g} / \mathrm{cm}^{3}$ to 1.345 $\mathrm{g} / \mathrm{cm}^{3}$ and the average is $1.304 \mathrm{~g} / \mathrm{cm}^{3}$.

The grain size and mineralogical characteristics of the modern bottom sediment of Lake Ulubat is strongly similar to those of Lake Manyas, probably as they undergo the same climatic and geological influences (Kazancı et al., 1998). However in some places in L. Ulubat, percentage volume of clay size particles is as much as silt, most probably because in this lake islands prevent and/or restrict water circulation during stormy periods. 


\subsection{Lacustrine pre-modern sediments}

\subsubsection{Thickness}

A total of eleven cores was obtained at three stations along a transect from the north shore (near the village of Bereketli) to the centre of L. Manyas (Fig. 2A). At station 1 (in the north) sampling penetrated to a sediment depth of $3.5 \mathrm{~m}$, at station 3(lake centre) it penetrated to a depth of $10.8 \mathrm{~m}$, whereas at station 2 (mid-way between the two other stations) it penetrated to a depth of $8 \mathrm{~m}$. Some previous drillings undertaken by the State Water Work of Turkey (DSI) around the lake showed that the thickness of Holocene deposits (mostly alluvial) is $12 \mathrm{~m}$ maximum and, lower down, Pleistocene red beds or Pliocene marl have been reached (Kazanc1 et al., 1997). Although the bedrock was not reached in the centre of the lake, it can reasonably be surmised by making use of the regional geomorphology, the history of the base level (the Sea of Marmara) and results from the alluvial plain drillings, that the total lacustrine sediment thickness is probably not much more than $10.8 \mathrm{~m}$.

In Lake Ulubat, the 2002 coring campaign concentrated on the eastern half of the lake (Fig. 2B). A series of 12 short cores (1 to $1.9 \mathrm{~m}$ ) was taken in a transect from the north to the south. A series of 12 longer cores $(5-7.8 \mathrm{~m})$ was obtained along the south-east shores of the lake. The longest core obtained by hand pushing could not penetrate further than $7.80 \mathrm{~m}$ depth because of a coarser-grained, organic-richer and partly compacted hard layer. Bottema et al. (2001) took a $7.2 \mathrm{~m}$ long core in 1988 in the delta (western basin). Their coring stopped on a thick sand layer (bottom $33 \mathrm{~cm}$ ). We assume that sediment thickness of Lake Ulubat may probably not be much more than $8 \mathrm{~m}$.

\subsubsection{Lacustrine sedimentary characteristics}

Overall, the Manyas core sediments are composed of silty mud and their sedimentary structures are homogenous. In places, there are only weak laminations marked by darker layers, varied degrees of bioturbation and rare horizons with degassing holes. The major change has been observed at around $3 \mathrm{~m}$ depth (station 1 ) and at $4 \mathrm{~m}$ (the other two stations). This distinct horizon is characterised by a brittle layer of a few $\mathrm{cm}$ thickness with occasional ostracod fragments and plant remains (henceforth "the brittle mixed layer"). Above and below this mixed layer, an unusually soft sediment was noted. At c. $60 \mathrm{~cm}$ below the brittle mixed layer, some core sections display distinct vertical black planar cracks at least $15-25 \mathrm{~cm}$ long with high magnetic susceptibility. In one of the core sections (core ML 5/5 of station 2), a mud load cast was observed just above the fractures. These features have been interpreted as signs of a seismic event by Leroy et al. (2002). 
The lithology of the pre-modern lacustrine sequence at three stations is typically a silty, plastic mud with a grey colour. The water content is about $45 \%$ at the top but it gradually decreases towards the bottom, to ca $30 \%$. Grain size analysis indicates dominance in the range of $2-35 \mu \mathrm{m}$. The volumetric ratios of sand, silt and clay along the cores are $1-5 \%, 45-80 \%$ and $25-45 \%$, respectively. Figure 6 shows the vertical grain-size distribution of the lacustrine sequence at station 3 from the combined results from cores ML 8/1-6, ML 9/1-3 and ML 11/1-2.In this core-long diagram of grain-size analysis, silt and clay content show a slight see-saw-type fluctuation, probably due to tenuous changes in sedimentation rates (Fig. 6). The silt is slightly coarser (35-50 microns) at the bottom of the sequence, particularly between 10.8 - $9 \mathrm{~m}$ at station 3. The transition is however not apparent by visual core inspection.

The mineralogy of the sediment is relatively similar to that of the modern lake bottom mud. Sand-size grains solely consisting of quartz and feldspar (plagioclase) occur, with rare heavy and magnetic minerals (epidote, garnet, clinopyroxene, magnetite) in some layers only. The other finer grains are made of calcite (minor), feldspar and abundant quartz. Smectite (57-95\%), kaolinite (1-30\%) and illite (0-20\%) are the clay components; all are allochthonous. Similar paragenetic results have been obtained from modern lake bottom sediments (see above).

In the $>500 \mu \mathrm{m}$-fraction, throughout core 11 , some black and/or orange, medium to coarse sand-sized, siderite and limonite grains (micronodules?) were detected. Their angular and/or lamellar shapes display an in situ origin (Fig. 6). SEM and EDS analyses show that the composition of these grains is not pure $\mathrm{FeCO}_{3}$ or $\mathrm{FeO}$, but a successive occurrence of limonite or siderite and illite bundles. Magnetite is also present within the sediment based on detections of magnetic susceptibility along the cores (Leroy et al., 2002; Løvlie, pers. comm. 2002). Formation of such Fe-mineral grains (siderite, limonite and magnetite) is not unusual in freshwater lakes, particularly by microbial activities in anaerobic environments (Konhauser, 1998; Warren and Haack, 2001). The iron content of the modern and old lake muds is relatively high, ca 8-9 \% (Table 5), and such a large iron content is generally created by high rates of sedimentation (Gerritse, 1999). In addition, there is a hot spring (Kızık Kaplıcası) just near the Kocaçay River and some of the iron content could be provided by discharge of this thermal water to the lake, although this is in need of clarification/confirmation.

Loss-on-Ignition analyses on $20 \mathrm{~cm}$-interval samples from the top $9 \mathrm{~m}$ of core 11 indicate a very homogenous sequence containing an average of $10 \%$ total organic matter and $12 \%$ carbonates. In contrast, results of chemical analyses together with heavy metal composition of the lacustrine mud show heterogeneous distributions (Table 5) suggesting sudden events or fast sediment transportation from onshore by floods. 
The biological content of the lake deposit has been described in some detail by Leroy et al. (2002). Shell fragments are only occasionally found within the sediment. Seed and ostracod assemblages are only preserved at around $4 \mathrm{~m}$ depth and $10.8 \mathrm{~m}$. These assemblages contain elements not typical of freshwaters but rather of euryhaline environments. The possible reason of their occurrence has been discussed in the cited study. An exploratory palynological diagram of the whole sequence indicates two different steps in the lake evolution. Shallow lake conditions with abundant Phragmites and aquatic vegetation were followed at c. $960 \mathrm{~cm}$ depth by open lake conditions (Leroy et al., 2002). The role of tectonics on this environmental change is not clear, maybe via a change in base level in the Marmara Sea; however it is also known that the Manyas-Karacabey depression has been tilting towards the east since the mid-Late Holocene.

Visual inspections of the sediments of Lake Ulubat (i.e. cores AK02LV 10/1-4, AK02PVC4) appear to be finer grained than those of Lake Manyas. Analyses of the upper part of the deposit by LOI indicate 6 to $9 \%$ organic matter and 7 to $14 \%$ carbonates.

\subsection{Sediment age}

In Lake Manyas, ${ }^{210} \mathrm{~Pb}$ and ${ }^{137} \mathrm{Cs}$ measurements were taken from the top $50 \mathrm{~cm}$ of core $8 / 1$ and from the top 25 $\mathrm{cm}$ of core 10/1, both from the lake centre at station 3 (Leroy et al., 2002). An average sedimentation rate in the region of $0.44 \mathrm{~cm} . \mathrm{yr}^{-1}$ was obtained (Fig. 8). Compaction with depth commonly leads to a down-core decrease in the accumulation rate; however, we might also expect a higher rate of sedimentation in the uppermost part of the core as most Turkish lakes have undergone intense siltation during recent times (Leroy et al., 2002).

The best materials for ${ }^{14} \mathrm{C}$ dating are the terrestrial seeds and aquatic plant matter at $10.80 \mathrm{~m}$ and $4.09 \mathrm{~m}$ in core 11. The uncal. ${ }^{14} \mathrm{C}$ age of the $10.80 \mathrm{~m}$ level is $3750 \mathrm{yr} \mathrm{BP}$ (beta-160591; $4100 \mathrm{cal}$. yr BP, calibrated according to Stuiver et al., 1998). A ${ }^{14} \mathrm{C}$ date at uncal. AD 240 (beta - 146142; cal. AD 350) has been obtained from the level of $4.09 \mathrm{~m}$. Since the source of carbon is partly aquatic, the date may have been affected by a slight reservoir effect. The true age is therefore likely to be within the $2 \mathrm{~s}$ bracket or slightly younger. This is different from a previous a simple age model (Bottema et al., 2001) where pollen evidence of the Beyşehir Occupation Phase (BOP)-type cultivars already occur at the base of a core taken on the southern shore suggesting that this $240 \mathrm{~cm}$-long sequence is at most $3200 \mathrm{yr}$ old, the assumed age of the beginning of the BOP (Eastwood et al., 1998). In Lake Ulubat, the Ducth authors found the presence of these same BO Phase-type indicators at $687 \mathrm{~cm}$ depth, hence suggesting a maximum age of 3200 years at the base. Bottema et al. (2001) also showed that BO Phase-type cultivars were present at various northern Anatolian 
lakes (i.e. lakes Abant, Kazgölü, Yeniçağa) commencing at different ages, but details of it are not within the scope of this study.

The surface or near surface sediment cores of the southern shelf of the Marmara Sea are mid and Late Holocene age most probably owing to loss during gravity coring (Çağatay et al., 2000). Within the upper 3 m, these sediments generally include sapropel layers that help to make a lateral correlation of the sequences (Çăgatay et al., 1999). The age of the 0.92-0.94 m layer in core 88, just in front of the Kocasu delta (Fig. 1B), is 2550 uncal. yr BP; but the age of an approximately similar layer (0.99-1.01 $\mathrm{m}$ in core GM-7) in the outer shelf margin is 7735 uncal. yr BP. In spite of this great difference in age in a N-S direction, ages of similar layers in thickness are close to each other in an E-W direction (Table 6). The 1.84-1.82 $\mathrm{m}$ layer in core 13 at $-70 \mathrm{~m}$ water depth (Fig 1B) is 3540 uncal. yr BP and it is 3640 uncal. yr BP in core GM-2 located at $-37 \mathrm{~m}$ b.s.l. (Çağatay et al, 2000). These data indicate that the sediment distribution in the southern shelf has been controlled probably by local morphology and prograding deltas.

\section{Discussion}

Lake Manyas has a relatively fine-grained, silt-dominated sedimentary sequence (Fig. 6), a consequence of being an open system. Whilst coarse grains are deposited at its margins forming a delta, the majority of clay-size particles is lost by outflowing water. During the field study we observed that the water of Lake Manyas was dark owing to sediments in suspension. The influence of this process, which creates a silty mud sedimentation, has been clearly detected by grain-size analyses of modern lake bottom sediments (Kazanc1 et al., 1997; Suliman, 1998). By the grainsize variation along the lacustrine sequence (Fig. 6), it can be concluded that firstly Lake Manyas has always been a shallow water body since its formation, and secondly sedimentation rates which are calculated by sediment thickness in such shallow lakes cannot explain directly the denudation of drainage basins as suggested by Einsele and Hinderer (1998), because fine particles are washed away. The suspended load of L. Manyas is moderate in comparison to central Anatolian rivers (e.g. Hay, 1994; EIE, 2000); however, such measurements and calculations of transported sediments may not be accurate as they do not take sufficient account of rare flood events or of human impact (Milliman et al., 1987; Einsele, 1992).

An improved approach to the problem of reconstructing denudation rates may be possible. At our study sites we benefit from the unique following two factors: suspended sediment load to Lake Manyas has been measured since 1961; and the recent, uppermost part of the sediment sequence formed by this load, has been radiometrically dated. Furthermore, some of the cores dated on the southern self (on the prodelta area of Kocasu River) and in the Gemlik Bay of the Marmara Sea contribute to give a holistic picture of the denudation rates of the continent. 


\subsection{Sedimentation rates in lakes Manyas and Ulubat}

Figure 8 shows sedimentation rates at different levels in the sediment sequence from Lake Manyas. The overall sedimentation rate in the last 10.8 meters is $0.29 \mathrm{~cm} \mathrm{yr}^{-1}$; however it increases from bottom to top. These values are similar, more or less, to other Turkish lakes in the Late Holocene (Inoue et al., 1998; Eastwood et al., 1999; Bottema et al., 2001) but they are relatively high in comparison to those of some other lakes in semi-arid climates (Einsele, 1992). Biogenic Fe-related minerals (siderite, limonite and magnetite) may form in environments receiving a moderate or fast sedimentation (Konkouser, 1998; Gerritse, 1999). The presence of such Fe-minerals within the sediment of Lake Manyas conform to a moderate sedimentation rate and the elimination of the majority of clay-size particles provide favourable conditions for porosity and hence for bacterial activity.

The very recent sediment accumulation rate of Lake Manyas (obtained from radionuclides) is $0.44 \mathrm{~cm} \mathrm{yr}^{-1}$ in the last $40 \mathrm{yr}$. Such a high rate of deposition is generally a lacustrine response to poor land-use and heavy deforestation (Einsele and Hinderer, 1998; Luque and Julià, 2002). From this it is possible to conclude that the lake surroundings and/or watershed catchment have undergone deforestation and poor agricultural practices leading to increased erosion in the $20^{\text {th }}$ century. The $20^{\text {th }}$ century situation may have resulted from the further disturbance of forests by human activity during the First and Second World Wars combined with poor land use. According to Holocene palynological diagrams, deforestation had already started several millenia ago in Anatolia (i.e. Bottema et al., 1993/1994; 2001; Roberts et al., 1997; 2001). More especially, the rise and the collapse of the Beyşehir Occupation Phase (c. $1300 \mathrm{yr}$ BC to c. AD 200-800 yr; Eastwood et al., 1998) will have caused important disturbance and vegetation successions.

Lake Ulubat has received its greatest suspended load from the drainage basin in the last $40 \mathrm{yr}$ (Table 4). However the total thickness of the lacustrine sequence in the southeastern part of the lake (core AK02LV10) is at least around $780 \mathrm{~cm}$. Bottema et al. (2001) attribute a maximum/minimum age of $3200 \mathrm{yr}$ BP (based on palynology) for the upper $650 \mathrm{~cm}$. It may be concluded that the sedimentation rate of Lake Ulubat is $>0.20 \mathrm{~cm} . \mathrm{yr}^{-1}$ in the Late Holocene. The relatively low sedimentation rate here may have resulted from the lake morphology (shallow depth, large outlet) that permits sediment loss and hence only a small part of the sediment is preserved in the lake. 
The comparison of sources (drainage areas + received load) and sinks (sediment thicknesses + sedimentation rates) between Lake Manyas and Lake Ulubat displays a paradox. Water discharges and sediment loads are significantly larger in Lake Ulubat but deposition rates and sediment thicknesses are lesser than those of Lake Manyas (Tables 2 and 4). Moreover, sediment measurements of EIE stations 302 and 317 (Fig. 1B) show a significant difference, indicating a large amount of suspended load has been retained in Lake Ulubat (Table 4). It is suggested that this difference results from the changing of measurement days at various stations and several other factors such as lake water depth, presence of sub-basins formed by islands, wave base and outlet position.

\subsection{Deposition rate in the Sea of Marmara}

The Marmara Sea is the base level of the Susurluk basin and hence it is the last sedimentation site for the surrounding drainage areas. The age of its sediments could provide reliable data for the evaluation of lacustrine sedimentation during the Late Holocene as sediments of both lakes Manyas and Ulubat and the southern shelf of the Marmara Sea are derived from the same drainage area (Fig. 1). Çağatay et al. (1999 and 2000) described and dated sediments taken by gravity coring. Marine cores that cover the time span of L. Manyas lacustrine sequence have been retrieved from the area offshore of the Kocasu River (the only outlet of the Susurluk drainage basin), but none in the delta itself. Each core is dated directly by at least one radiocarbon date (uncalibrated and uncorrected for reservoir effectand many have in addition gone through a well-known 15-50 cm thick sapropelic layer. This was deposited between c. 4750 and $3500{ }^{14} \mathrm{C}$ yr BP in a relatively warm sea water and a wet climate (Çağatay et al., 2000). Hence for most cores two chronological anchoring points are available. The six cores with sapropels were collected at $37 \mathrm{~m}$ (GM2), $49 \mathrm{~m}$ (core 88), $72 \mathrm{~m}$ (GM-4), $99 \mathrm{~m}$ (GM-6), $70 \mathrm{~m}$ (core 13) and $110 \mathrm{~m}$ (core 22) water depth of the inner southern shelf and one at $370 \mathrm{~m}$ (GM-7) water depth on the outer shelf. Cores GM-2 and 88 are on the prodelta areas of the Gönen and Kocasu deltas respectively (Figs 1 and 9).Due to gravity coring, the top part of the cores containing maybe the last centuries, is usually missing . The sediment is generally olive grey, clayey and silty mud with Mediterranean marine molluscs, echinoderms and foraminifera. It contains $0.6-2.9 \%$ of organic carbon $\left(\mathrm{C}_{\mathrm{org}}\right)$ and $7-20 \%$ of total carbonate as $\mathrm{CaCO}_{3}$. The latter is higher in the upper $1 \mathrm{~m}$ of the core sequence (deposited since ca $3500 \mathrm{yr} \mathrm{BP}$ ) than in the lower part of the sequence, and is mostly of biogenic origin (Çağatay et al., 2000). Grain size decreases significantly from the silt-dominated inner-shelf to the clay-dominated outer shelf. Inorganic particles are mostly quartz, feldspar, kaolinite and illite. This mineralogical composition is similar to that of lake sediments, confirming the fluvial origin. 
Holocene sedimentation rates on the southern Marmara shelf have varied from $0.052 \mathrm{~cm} \mathrm{yr}^{-1}$ on the inner shelf (Core 13) to $0.018 \mathrm{~cm} \cdot \mathrm{yr}^{-1}$ on the outer shelf (Core GM-6) (Table 6). On a submarine plateau (Core GM-7), the rate has been $0.013 \mathrm{~cm} . \mathrm{yr}^{-1}$ since $7700 \mathrm{yr}$ BP (Çağatay et al., 2000). However the average accumulation rates of the southern shelf based on sediment thickness is $0.04 \mathrm{~cm} \cdot \mathrm{yr}^{-1}$. It is 0.036 and $0.047 \mathrm{~cm} . \mathrm{yr}^{-1}$ for the Late Holocene on the prodeltas of Kocasu and Gönen deltas according to cores 88 and GM-2 respectively which are c. 10 km away from rivers' mouths (Fig. 1). This higher rate of deposition must be related to processes of delta formation. It is also noteworthy that the rates are relatively high in bays (Table 6) probably due to mass movements together with submarine currents particularly during seismic events. However, both average and individual deposition rates of the shelf are five to twenty times less than in L. Manyas $\left(0.29 \mathrm{~cm} \mathrm{yr}^{-1}\right)$.

\subsection{Erosion and denudation rate in the southern continental Marmara region}

Measurements of suspended sediment load by EIE observatories show that the southern Marmara region, particularly the Susurluk drainage basin, has recently been subject to relatively strong erosion. Suspended sediment production of the Susurluk basin is an average of only c. 128 ton. $\mathrm{yr}^{-1} \cdot \mathrm{km}^{2}$ according to observations on four rivers (EIE stations 314, 316, 302 and 321, Fig. 1) during the last 45 years, however it decreases to c. 122 ton. $\mathrm{yr}^{-1} \cdot \mathrm{km}^{2}$ in the last 27 years (Table 4). These values are obtained by dividing the average annual load of a river to its net drainage area. In the whole southern Marmara region, when the drainage areas of the rivers Gönen (EIE Station 210) and Biga are added to the Susurluk basin, the average suspended sediment production becomes 79 ton. $\mathrm{yr}^{-1} \cdot \mathrm{km}^{2}$ in the last 25 years. This lower figure is probably due to the lower relief of the western part of the basin. To obtain the value of the net erosion (suspended and bed load), $35 \%$ of it should be added to the suspended load due to the river discharge characteristics.

In Lake Manyas, the sedimentation rate during the last 45 years is $0.44 \mathrm{~cm} . \mathrm{yr}^{-1}$ but the average has been around $0.29 \mathrm{~cm} . \mathrm{yr}^{-1}$ during the lake history. The former rate is equivalent to a sediment production of 46 ton. $\mathrm{yr}^{-1} \mathrm{~km}^{2}$ from the drainage area of Lake Manyas in the same time interval according to the data of EIE station 314 (Table 4). From here, one can conclude that even erosion of the Lake Manyas drainage area has fluctuated in the Late Holocene and its rate nearly doubled in the last century (Fig. 9). The same situation is expected for the whole southern continental Marmara region in spite of a slight decrease in the last 25 years. 
The amount of sediment body deposited in a reservoir is the critical point for interpretation of surface sedimentary processes; however it is difficult to define it precisely. Figure 10 shows a possible holistic model of erosion and sedimentation in the Susurluk basin. It is based on equilibrium between erosion (input) and sedimentation (output) as given by Einsele and Hinderer (1998). Theoretically, the amount of transported and deposited sediment should be equal and Lake Manyas could be a relatively convenient reservoir to control the model. The amount of sediment body in the lake could be estimated roughly from the surface area of the lake and the sediment thickness provided by coring; however this is not sufficient for a precise result. The other approach could be to use the duration of the sedimentation (i. e. the time span of the reservoir) and the average rate of deposition for the calculation of the sediment mass into the lakes. The results obtained by alternative variables show a large difference. Using an average sedimentation rate in calculations has resulted in extra sediment thickness or shorter deposition times rather than dated by radiometric methods. Probably this is why Lake Manyas is an open system. We tried alternative calculations and concluded that the accumulation of the present sediment mass in lakes Manyas and Ulubat was not likely to be explained by the present sedimentation rates without taking into account all variables together (i.e. duration, surface areas of lakes, maximum and mean sediment thickness, possible sediment mass, suspended and bed load provided, sediment loss by outlets, sediments provided by deflation, lake floods and water level changes). Therefore, it is suggested that holistic models should?/could be used for closed lakes and marine systems.

\section{Conclusions}

NW Anatolia including the southern Marmara region is one of the most rapidly degrading parts of Turkey. The erosion values and/or denudation rates of the Susurluk drainage basin are significantly higher than other less vegetated areas (i.e. Einsele, 1992). In addition to deforestation, erodibility of source rocks and possibly agriculture itself must also be effective. This study has focused on numerical characterization of erosion using sedimentation rates in lakes and for the shelf sediments of the Marmara Sea combined with the suspended sediment load of modern rivers. Our results fall in three categories;

a) Marine and lacustrine sedimentations in the region have changed since the mid-Holocene in parallel and/or with a time-shift of c. 300 yrs (Fig. 9 A-C). The average of accumulation rate based on ratio of sediment thickness and age is around 0.20 and $0.29 \mathrm{~cm} \cdot \mathrm{yr}^{-1}$ in lakes Ulubat and Manyas respectively and between 0.018 $0.052 \mathrm{~cm} . \mathrm{yr}^{-1}$ in the southern shelf of the Marmara Sea. In Lake Manyas, the sedimentation that reflects local erosion has increased over the period from $3750-1710 \mathrm{yr}$ BP to 1710 -present from a rate of $0.22 \mathrm{~cm}^{\mathrm{yr}}{ }^{-1}$ to $0.24 \mathrm{~cm} . \mathrm{yr}^{-1}$ respectively (Figs $8 \& 9$ ). For the last $45 \mathrm{yr}$, sedimentation rates and/or erosion has further 
increased considerably. Its denudation value is 127 ton. $\mathrm{yr}^{-1} \cdot \mathrm{km}^{2}$. This is most probably due to mismanagement of the land and a rapid decrease in the forest cover whilst the other regional characteristics such as source rock, morphology and size of the drainage area have remained the same.

b) Lake Manyas has always been a shallow $(<4 \mathrm{~m})$ fresh water body. Palaeolimnological features as well as sediment composition were the same during the Late Holocene except for a period of marsh conditions at the base of the sedimentary record. Its sedimentary infill is composed of a clayey silt or silty mud as the majority of clay size particles were eliminated via the outlet. This is consistent with the presence of a fair amount of clay size particles in modern suspended load brought in by the River Kocaçay. The same situation is also observed in Lake Ulubat. Compaction or decrease of porosity by sediment loading is negligible within the deposits. The only diagenetic mineral is siderite (iron carbonate) that is randomly disseminated in lacustrine mud (see above) and occurrence of this mineral needs a strong bacterial activity together with a partly porous environment. Its presence throughout the lake sequence may indicate that environmental conditions have remained the same.

c) In an open lake system such as L. Manyas, denudation rates of the drainage basin cannot be solely reconstructed by sedimentation rates in the lake, as a very important grain size fraction, i. e. clay, is dramatically under represented. Comparisons of present sediment thickness, possible volume of infill, sedimentation rate, age of sediment and the modern denudation rate indicate an imbalance between inputs and outputs in a lacustrine depositional environment. The lakes Manyas and Ulubat should have filled much faster according to both average and present denudation rates. This is very typical in Lake Ulubat where annual sediment load discharge is very large (Tables 3 and 4). From here it can be concluded that sedimentation in reservoirs (= erosion on land) was not regular even if it increased in time. Probably it was dramatically fast for short periods and then it was slower for a relatively long time, in spite of a generally increasing trend for long periods. The 20th century, particularly the last 45 years, has been such a period of intensive erosion in the Susurluk basin. We have already observed in the field and at the EIE station 317, that the lake outlet carries a high volume of suspended sediments. The apparent consequence of the trapping of the silty and coarser grains is to provide very fine sediment to the southern shelf of Marmara Sea. Hence, a deposition rate based on sediment thickness in this marine environment cannot be correlated directly with rates in lakes, neither with denudation of the drainage basin. Also, the effect of the tectonism on sedimentation is not detectable when the time span is very short. 


\section{Acknowledgements}

Geological and limnological studies were supported by a project (code no: TUBITAK- YDABCAG 456/G) of the National Marine Research Programme realised by joining of State Planning Organisation (DPT), Scientific and Technical Research Council of Turkey (TUBITAK) and General directorate of Mineral Research and Exploration (MTA), with a coordination of Naci Görür of TUBITAK-MAM. The two lake coring campaigns were funded by NATO grants (CRG 973155 and CLG 978645) and partly by MTA. Sediment samples were analysed in laboratories of Ankara University (AU), Brunel University (BU) and Gebze Institute of Technology (GYTE). The authors are also grateful to Dr. Baki Varol (AU) for determination of iron minerals, to Dr. Z. Aktaş (AU) for grain-size analyses and to Mr Ali Aydemir (GYTE) for drawing of the figures. The journal reviewers, Dr T.J. Wilkinson (Chicago, USA) and particularly an anonymous one appreciably contributed to improve an early version of the paper. The authors are also indebt to Mike Turner (BU) for improving the English of the manuscript.

\section{References}

Aksu, A.E., Hiscott, R.N., Yaşar, D., 1999. Oscillating Quaternary water levels of the Marmara Sea and vigorous outflows into the Aegean Sea from the Marmara Sea-Black Sea drainage corridor. Marine Geol. 153, $275-302$.

Algan, O., Çağatay, N.M., Tchepalyga, A., Ongan, D., Estoe, C., Gokaşan, E., 2001. Stratigraphy of the sediment infill in Bosphorus strait: water exchange between Black Sea and Mediterranean Sea during the last glacial Holocene. Geo-Mar Letters 20, 209-218.

Altınsaçlı, S., Griffiths, H. I., 2001. Ostracoda (Crustacea) from the Turkish Ramsar site of Lake Kus (Manyas Gölü). Aquatic Conservation: Marine and Freshwater Ecosystems 11: 217-225.

Arçak, S., Haktanır, K., Kibar, M., Dengiz, O., 2000. Ecological changes in Manyas Lake related to boron pollution and water regime. Proc. of Internat. Symp. on Desertification. Konya 13-17 June 2000. TÜBITAK, 73-80.

Bayhan, E., Şahbaz, A, Görmüş, S., Özdoğan, M, Yakupoğlu, T., Temel, A., 1997, Guney Marmara, KaracabeyBandirma bolgesi Orta-Ust Miyosen istifinin mineralojik incelenmesi.In: Marmara Denizi Güneyi Kıyı ve Kıyı Ard1 Istiflerinin Stratigrafisi, Sedimantolojisi ve Morfotektonigi. TUBITAK Raporu, YDABCAG - 598/G, s. 2128.

Beug, H.-J., 1967. Contribution to the postglacial vegetational history of northern Turkey. In: Cushing, E., Wright, H. (Eds), Quaternary palaeoecology. Yale Univ. Press, Connecticut, pp. 349-356. 
Bottema, S., Woldring, H., 1993/1994, Late Quaternary vegetation history of northern Turkey. Palaeohistoria 35/36,13-71.

Bottema, S., Woldring, H., Kayan, I., 2001, The Late Quaternary vegetation history of western Turkey. In: The Ilipinar Excavations II (Eds. J.J. Roodenberg and L.C. Thissen), Nederlands Instituut Voor Het Nabije Oosten, Leiden, pp. 327-354.

Çağatay, N., Algan, O., Sakınç, M., Eastoe, C.J., Egesel, L., Balkis, N., Ongan, D., Caner, H., 1999, A mid-late Holocene sapropelic sediment unit from the southern Marmara sea shelf and its palaeoceanographic significance. Quaternary Sci. Rev., 18, 531-540.

Çağatay, M.N., Görür, N., Algan, O., Eastoe, C., Tchapalyga, A., Ongan, D., Kuhn, T., Kuscu, I., 2000. Last glacialHolocene palaeoceanography of the Sea of Marmara: timing of last connections with the Mediterranean and the Black Seas. Mar. Geol. 167, 191-206.

Chorley, R.J., Schumm, S.A., and Sugden, D.E., 1984, Geomorphology. Methuen, London, 605 p.

Eastwood, W. J., Roberts, C. N., Lamb, H. F., 1998. Palaeoecological and archaeological evidence for human occupance in southwest Turkey: the Beysehir Occupation Phase. Anatolian Studies 48, 69-86.

Eastwood, W. J., Roberts, C. N., Lamb, H. F., Tibby, J.C., 1999, Holocene environmental change in southwest Turkey; a palaeoecological record of lake and catchment-related changes. Quaternary Sci. Rev., 18, 671-695.

EIE, 1993. Turkiye akarsularinda sediment gözlemleri ve sediment taşınım miktarları. EIEI Genel Müdürlüğü, yayın no 87-44, Ankara.

EIE, 2000. Turkiye akarsularinda suspanse sediment gozlemleri ve sediment tasinim miktarlari (Suspended sediment data and sediment transport amount for surface waters in Turkey). EIEI Genel Müdürlüğü, yayın no 20-17, Ankara.

Einsele, G., 1992. Sedimentary Basins: Evolution, Facies and Sediment Budget. Springer, Berlin, 628 pp.

Einsele, G. and Hinderer, M., 1998. Quantifying denudation and sediment accumulation systems (open and closed lakes): basic concepts and first results. Palaegeography, Palaeoclimatology, Palaeoecology 140, 7-21.

Emre, Ö., Erkal, T., Kazanc1, N., Görmüş, S., Görür, N., Kuşçu, I., 1997a. Guney Marmara'nin Neojen ve Kuvaterner' deki morfotektonigi. In: Güney Marmara Bolgesinin Neojen ve Kuvaterner Evrimi -Proje raporu- (Neogene and Quaternary Evolution of southern Marmara Region, A project report for Turkish Scientific and Research Council) TUBITAK, YDABCAG-426/G, Ankara, 36-68.

Emre, Ö., Kazancı, N., Erkal, T., Karabıyıkoglu, M., Kuşçu, I., 1997b. Ulubat ve Manyas göllerinin oluşumu ve yerleşim tarihcesi. In: Güney Marmara Bolgesinin Neojen ve Kuvaterner Evrimi -Proje raporu- (Neogene and 
Quaternary Evolution of southern Marmara Region, A project report for Turkish Scientific and Research Council) TUBITAK, YDABCAG-426/G, Ankara, 116-134

Emre, Ö., Görür, N., Erkal, T., Islamoğlu, Y., Sakınc, M., Keçer, M., Akkök, R., 1999. Formation of Sakarya river delta and sea-level changes in the Black Sea in latest Pleistocene-Holocene. TUBiTAK-Universite-MTA Ulusal Deniz Arastirmalari Programi WORKSHOP IV (24-25 Mayis 1999), Extended Abstracts, Ankara, pp.51-58.

Erdoğan,T., 1988. Balikesir Iklim Etüdü. Devlet Meteoroloji Ipleri Genel Müdürlügü, Ankara.

Ergin, M., Kazanc1, N., Varol, B., İleri, Ö., Karadenizli, L. and Kuşçu, İ., 1997. Sea-level changes and related depositional environments on the southern Marmara shelf. Marine Geology 140: 391-403.

Fritz, S.C., 1996. Paleolimnological records of climatic change in North America. Limnology and Oceanography 41,882-889

Gerritse, R.G., 1999. Sulphur, organic carbon and iron relationships in estuarine and freshwater sediments; effects of sedimentation rate. Applied Geochemistry 14, 41-52.

Görür, N., Çağatay, M.N., Emre, O., Alpar, B., Sakınc, M., Islamoğlu, Y., Algan, O., Erkal, T., Keçer, M., Akkök, R., Karlık, G., 2001. Is the abrupt drowning of the Black Sea shelf at 7150 yr BP a myth? Mar. Geol. 176, 65-73.

Hay, B.J., 1994, Sediment and water discharge rates of Turkish Black Sea rivers before and after hydropower dam construction. Environental Geology 23, 276-283.

Hurst, H.E., 1950, Long-term storage capacity of reservoirs. Am. Soc. Civil and Grs. Trans., 116, 770-808.

Inoue, K., Saito, M., Naruse, T., 1998, Physicochemical, mineralogical, and geochemical characteristics of lacustrine sediments of Konya Basin, Turkey, and their significance in relation to climatic change. Geomorphology 23, 229-243.

Kazanc1, N., Bayhan, E., Suliman, N., Sahbaz, A., Ileri, Ö., Özdogan, M., Temel, A., Ekmekçi, M., 1997. Manyas Gölü ve Güncel tortullari. Lake Manyas and its recent sediments. In: Neogene and Quaternary Evolution of Southern Marmara Region, Report for Turkish Sci. Tech. Res. Council (TÜBITAK), Project no. YDABCAG-426/G, Ankara, pp. 192-238.

Kazanc1, N., Emre, Ö., Erkal, T., Ileri, Ö., Ergin, M., Görür, N., 1999. Morphology and sedimentary facies of modern Kocasu and Gonen rivers deltas, northwestern Anatolia. Mineral Res. Expl. Bul. Turkey 121: 1-18.

Kazancı, N, Ileri, O., Suliman, N., Özdoğan, M., Bayhan, E., Şahbaz, A., Gencer, A, Ergin, M., Erkmen, C., 1998. Ulubat Golu'nde guncel tortullasma / Recent sedimentation in Lake Ulubat. In: Marmara Denizi Güneyi Kiyı 
ve Kıyı Ardı Istiflerinin Stratigrafisi, Sedimantolojisi ve Morfotektonigi. TUBITAK Raporu, YDABCAG 598/G, s. 99-145.

Koçman, A., 1993. Türkiye iklimi. Ege University, Izmir.

Konhauser, K.O., 1998. Diversity of bacterial iron mineralization. Earth Sci. Rev., 43, 91-121.

Lasanta, T., Garcia-Ruiz, J.M., Perez-Rontome, C., Sancho-Marcen, C., 2000. Runoff and sediment yield in a semi-arid environment : the effect of land management after farmland abandonment. Catena 38, 265-278.

Leopold, L.B., Wolman, M.G., Miller, J.P., 1995. Fluvial Processes in Geoorphology. Dover Pub., NewYork, 522 p.

Leroy S., Kazancı N., Ileri Ö., Kibar M., Emre O., McGee E. and Griffiths H. I. 2002. Abrupt environmental changes within a late Holocene lacustrine sequence south of the Marmara Sea (Lake Manyas, N-W Turkey): possible links with seismic events Special issue of Marine Geology on "Quaternary Tectonic and PaleoclimaticPaleoceanographic Evolution of the Marmara Sea and Environs: a collection of papers dedicated to the memories of Drs. Ihsan Ketin and Aykut Barka". Edited by A. Aksu. 190/1-2 pp. 531-552

Luque, J.A. and Julià, R., 2002. Lake response to land-use and climate change during the last 1000 years in the oligotrophic Lake Sanabria (northwest of Iberian Peninsula). Sedimentary Geol., 148, 343-355.

Milliman, J.D., Qin, Y.S., Ren, M.E., Saito, J., 1987. Man's influence on the erosion and transport of sediment by Asian rivers: the Yellow River (Huanghe) example. J. Geol. 95, 751-762.

Morgan, R.P.C., 1986, Soil erosion and conservation. Longman, London, 298 pp

Okay, A. I., Siyako, M., Burkan, K. A., 1991. Biga Yarimadasinin jeolojisi ve tektonik evrimi. Türkiye Petrol Jeologlari Dernegi Bult., 2, 83-121.

Özdemir, D.A., Kırmızıül, H., 1997. 1996 yılı Türkiye Iklimi. Devlet Meteoroloji Işleri Genel Müdürlügü, Ankara.

Roberts, N, Eastwood, W.J., Lamb, H.F., Tibby, JC., 1997. The age and causes of Mid-Late Holocene environmental change in southwest Turkey. In: Third Milenniun BC Climate Change and Old World Collapse (H.Z. Dalfes, G. Kukla, H. Weiss, Eds.), NATO ASI Series, vol. 49, Springer-Verlag, Berlin, Heidelberg, 409-429.

Roberts, N, Reed, J.M., Leng, MJ., Kuzucuoglu, C., Fontugne, M., Bertaux, J, Woldring, H., Bottema, S, Black, S., Hunt, E., Karabiyikoglu, M, 2001. The tempo of Holocene climatic change in the eastern Mediterranean region: new high-resolution crater-lake sediment data from central Turkey. The Holocene 11, 721-736

Ryan, W. B. F., Pitman, W. C., Major, C.O., Shimkus, K., Moskalenko, V., Jones, G. A., Dimitrov, P., Gorur, N., Sakinc, M., Yuce, H., 1997. An abrupt drowning of the Black Sea shelf. Mar. Geol. 138, 1-2, 119-126

Suliman, N., 1998. Recent Sedimentation in Lake Manyas. MSc thesis, Graduate School of Ankara University, Ankara. 
Stuiver, M, Reimer, P. J., Bard, E., Beck, J. W., Burr, G. S., Hughen, K. A., Kromer, B., McCormic, G., Van der Plicht, J., Spurk, M., 1998. INTCAL98 radiocarbon age calibration, 24,000-0 cal BP. Radiocarbon 40, 1041-1083.

Verschuren, D., 1999. Sedimentation control on the preservation and time resolution of climate-proxy records from shallow fluctuating lakes. Quaternary Sci. Rev., 18, 821-837.

Warren, A. and Haack, E.A., 2001. Biochemical controls on metal behaviour in freshwater environments. Earth Sci. Rev., 54, 261-320.

Yılmaz, Y., Gürpınar, O., Genç, S.C., Bozcu, M., Yılmaz, K., Şeker, H., Yiğitbaş, E., Keskin, M., 1990. Geology of Armutlu Peninsula and its surrounding. A Turkish report for Turkish Petroleum Company (TPAO), no 2796, 210pp, Ankara (unpublished).

Zohary, M., 1973. Geobotanical foundations of the Middle East. G. Fisher Verlag, Stuttgart. 

Table 1. Average climatic elements in NW Anatolia according to Bandirma Meteorological station since 1933

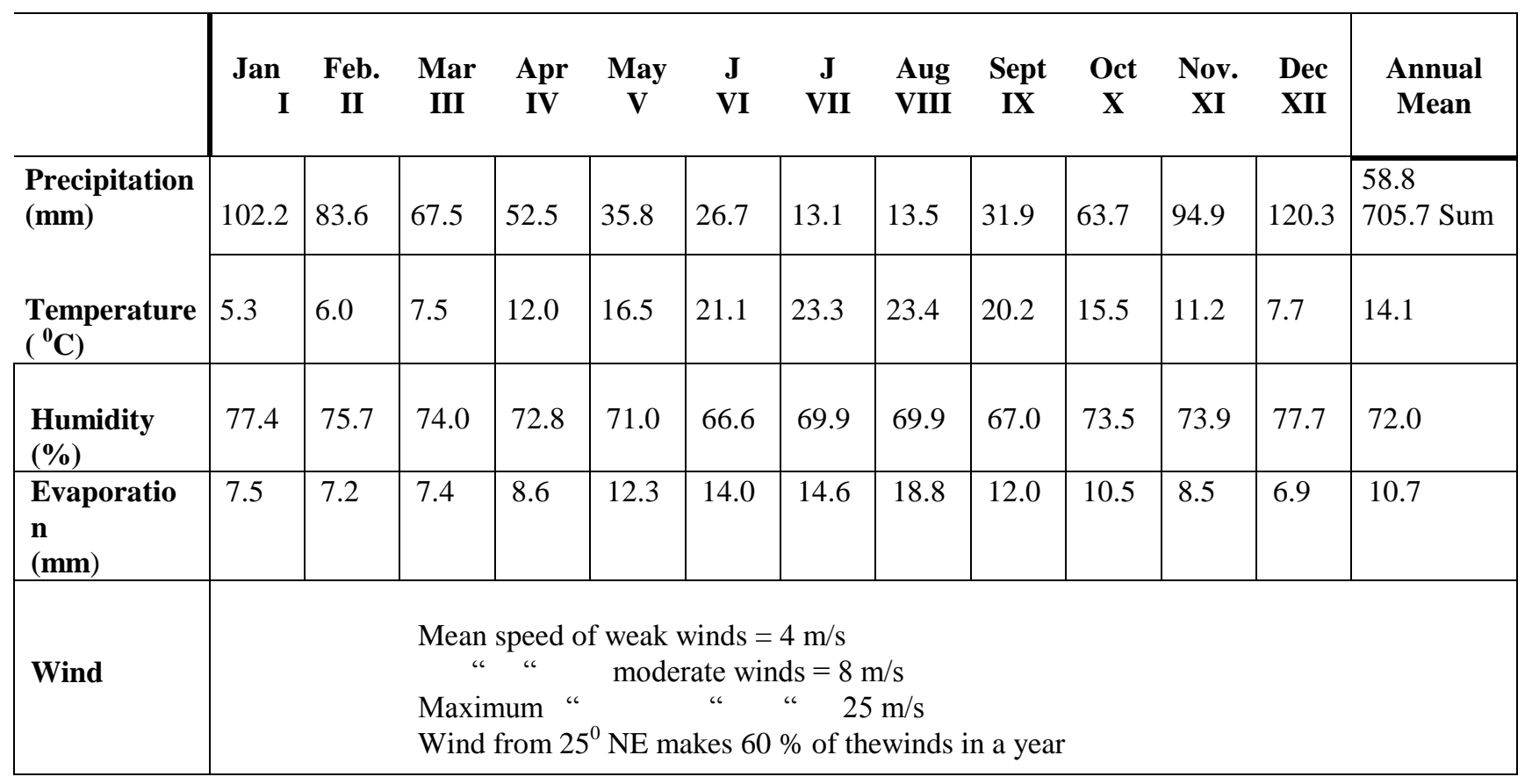



Table 2. Annual water and suspended sediment discharge into Lake Manyas by the River Kocaçay (calculated from EIE, 2000)

\begin{tabular}{|c|c|c|c|c|c|c|c|c|c|c|}
\hline \multirow{2}{*}{$\begin{array}{l}\text { Measurements } \\
\text { YEARS }\end{array}$} & \multirow{2}{*}{\multicolumn{3}{|c|}{ Discharge $\left(\mathrm{m}^{3} / \mathrm{s}\right)$}} & \multirow{2}{*}{\multicolumn{3}{|c|}{$\begin{array}{l}\text { Concentration } \\
\text { ppm }\end{array}$}} & \multicolumn{3}{|c|}{$\begin{array}{l}\text { Sediment Load } \\
\text { (ton/day) }\end{array}$} & \multirow{2}{*}{$\begin{array}{l}\text { Sand in } \\
\text { suspended load, } \\
\text { mean }(\%) \\
\end{array}$} \\
\hline & & & & & & & Mean & Max. & Min. & \\
\hline 1971 & 11.4 & 21.2 & 0.9 & 126.1 & 245 & 73 & 131.5 & 431.9 & 6.7 & 18.37 \\
\hline 1972 & 21.7 & 106.7 & 0.6 & 293.8 & 1070 & 63 & 1522.2 & 9664.2 & 5.4 & 12.18 \\
\hline 1973 & 14.8 & 50.7 & 0.7 & 157 & 470 & 45 & 139.1 & 395.4 & 7.7 & 0.0 \\
\hline 1974 & 37.3 & 216.6 & 0.5 & 204.7 & 813 & 32 & 1886.6 & 15214.7 & 5.0 & 0.0 \\
\hline 1975 & 19.2 & 79.6 & 0.9 & 114.9 & 319.6 & 32 & 297.1 & 2194.0 & 4.2 & 0.0 \\
\hline 1976 & 23.8 & 71.2 & 1.0 & 396 & 1890 & 27 & 1394.2 & 7136 & 2.5 & 14.5 \\
\hline 1977 & 7.97 & 17.0 & 0.3 & 51.5 & 118.0 & 15 & 34.04 & 128.4 & 1.3 & 34.0 \\
\hline 1978 & 48.0 & 364.3 & 0.9 & 141.5 & 470 & 35 & 1699 & 14793.5 & 3.8 & 29.4 \\
\hline 1979 & 13.5 & 58.6 & 0.6 & 82.6 & 249.0 & 23 & 171.4 & 1260.7 & 3.0 & 32.5 \\
\hline 1980 & 2874 & 103.2 & 0.9 & 338.0 & 2180 & 30 & 1967.2 & 19438 & 3.0 & 7.8 \\
\hline 1981 & 130.6 & 1088 & 0.9 & 383.5 & 2120 & 25 & 19249.4 & 199286.7 & 2.0 & 0.0 \\
\hline 1982 & 15.8 & 76.8 & 0.5 & 94.5 & 266.0 & 26 & 242.4 & 1765.2 & 2.6 & 0.0 \\
\hline 1983 & 15.8 & 68.6 & 0.6 & 129.9 & 746.0 & 15 & 482.4 & 4421.6 & 3.3 & 13.7 \\
\hline 1984 & 24.1 & 96.3 & 0.6 & 162.3 & 797.0 & 24 & 431.4 & 3145.0 & 1.8 & 10.1 \\
\hline 1985 & 18.7 & 133.5 & 0.2 & 896.8 & 8298.0 & 17 & 8860.5 & 95710.3 & 0.4 & 12.5 \\
\hline 1986 & 42.2 & 354.2 & 0.1 & 213.4 & 1344.0 & 11 & 3716.5 & 41135.4 & 0.2 & 16.5 \\
\hline 1987 & 42.5 & 181.1 & 0.07 & 298.6 & 1451.0 & 15 & 862.0 & 18556.4 & 0.5 & 15.3 \\
\hline 1988 & 11.6 & 55.0 & 0.2 & 52.1 & 128.0 & 20 & 57.1 & 290.3 & 0.6 & 4.4 \\
\hline 1989 & 3.8 & 9.6 & 0.1 & 145.8 & 833.0 & 17 & 78.1 & 694.0 & 0.1 & 8.0 \\
\hline 1990 & 14.5 & 107.9 & 0.2 & 16.8 & 1367.0 & 18 & 1286.7 & 12744.3 & 0.7 & 11.0 \\
\hline 1991 & 10.9 & 32.4 & 0.4 & 221.9 & 1551.8 & 24 & 450.5 & 3576.1 & 1.4 & - \\
\hline 1992 & 23.6 & 116.5 & 0.2 & 237.3 & 973.5 & 10 & 1364.5 & 9796.6 & 0.4 & - \\
\hline 1993 & 29.0 & 217.6 & 0.2 & 121.8 & 604.1 & 13 & 1068.4 & 11357.8 & 0.6 & - \\
\hline 1994 & 6.7 & 17.4 & 0.4 & 61.8 & 253.5 & 16 & 50.1 & 195.2 & 0.2 & - \\
\hline 1995 & 33.9 & 295.0 & 0.8 & 99.8 & 810.9 & 10 & 1762.5 & 20669.9 & 1.4 & - \\
\hline 1996 & 9.8 & 38.8 & 0.3 & 134.7 & 834.5 & 09 & 221.9 & 1369.0 & 0.4 & - \\
\hline 1997 & 18.4 & 91.3 & 0.6 & 111.6 & 398.9 & 14 & 378.6 & 1864.7 & 1.6 & - \\
\hline 1998 & 12.4 & 34.8 & 0.5 & 67.9 & 187.1 & 20 & 75.9 & 207.9 & 2.5 & - \\
\hline 1999 & 36.0 & 150.9 & 0.8 & 194.3 & 958.1 & 21 & 1936.6 & 12492.6 & 3.5 & - \\
\hline 29 years & 25.2 & 1088 & 0.052 & 174.6 & 2180.0 & 9.0 & 1861.8 & 199286.8 & 0.1 & \\
\hline
\end{tabular}


Table 3. Monthly water discharge and suspended sediment transport by the River Kocaçay (calculated from EIE, 2000)

\begin{tabular}{c|l|l|l|l|l|l|l|l|l|l|l|l|l} 
Months & I & II & III & IV & V & VI & VII & VIII & IX & X & XI & XII & Mean \\
\hline $\begin{array}{c}\text { Water } \\
\mathbf{m}^{\mathbf{3}} / \mathbf{s}\end{array}$ & 53.43 & 56.13 & 47.16 & 28.37 & 8.45 & 3.16 & 1.84 & 0.52 & 0.54 & 5.01 & 12.80 & 60.16 & 23.14 \\
\hline $\begin{array}{c}\text { Load } \\
\text { ton/day }\end{array}$ & 3357.4 & 2320.6 & 1753.6 & 885.5 & 53.16 & 33.54 & 34.22 & 2.59 & 4.38 & 272.9 & 3747.6 & 8307.9 & 1421.9 \\
\hline
\end{tabular}

Table 4. Summary of observations about suspended load by the main rivers of the southern Marmara region (From EIE, 1993; 2000). Abbreviations: a.s.l: above sea level, AGS: observation interval for water discharge, SGS: observation interval for sediment, $\mathrm{Q}_{\mathrm{s}}$ : sediment; Q: water discharge; $\mathrm{R}^{2}$ : coefficient constant. Sediment production in AGS and SGS is calculated by means of related formula.

\begin{tabular}{|c|c|c|c|c|c|c|c|c|c|c|c|c|c|}
\hline \multirow{3}{*}{ 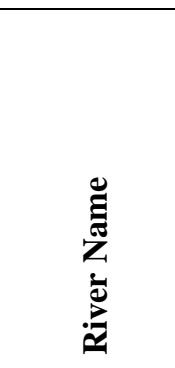 } & \multirow{3}{*}{ 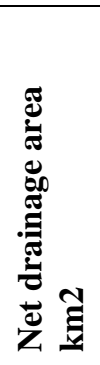 } & \multicolumn{2}{|c|}{$\begin{array}{c}\text { EIE } \\
\text { Observator } \\
\mathbf{y}\end{array}$} & \multicolumn{2}{|c|}{$\begin{array}{c}\text { Observation Interval } \\
\text { (year) }\end{array}$} & \multicolumn{8}{|c|}{ AV. SEDIMENT MEASURED IN YEARS } \\
\hline & & \multirow[b]{2}{*}{ 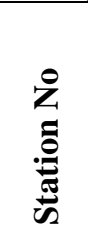 } & \multirow[b]{2}{*}{ 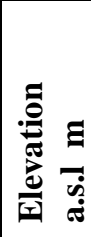 } & \multirow[b]{2}{*}{$\begin{array}{c}\text { Discharge } \\
\text { (AGS) }\end{array}$} & \multirow[b]{2}{*}{$\begin{array}{l}\text { Sediment } \\
\text { (SGS) }\end{array}$} & \multicolumn{2}{|c|}{ Key curve for SGS } & \multirow[b]{2}{*}{ 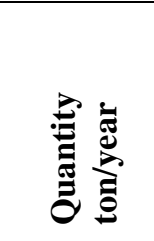 } & \multicolumn{2}{|c|}{$\begin{array}{l}\text { Production } \\
\text { ton. }^{-1} \mathbf{. k m}^{2}\end{array}$} & \multicolumn{2}{|c|}{ Type \% } & \multirow[b]{2}{*}{ 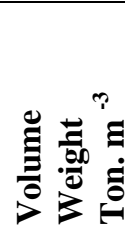 } \\
\hline & & & & & & Equality & $\mathbf{R}^{2}$ & & $\underset{4}{4}$ & $\mathfrak{n}$ & ర్జ & 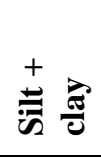 & \\
\hline Gönen & 1193 & 210 & 57 & 1971-1994 & $1972-1995$ & $\begin{array}{c}\mathrm{Q}_{\mathrm{s}}=1.9475 \mathrm{x} \\
\mathrm{Q}^{1.2485}\end{array}$ & 0.816 & 26.048 & 24 & 22 & 28.3 & 71.7 & 1.24 \\
\hline $\begin{array}{l}\text { Mustafa } \\
\text { Kemalpaşa }\end{array}$ & 8480 & 302 & 40 & 1938-1996 & 1964-1999 & $\begin{array}{c}\mathrm{Q}_{\mathrm{s}}=1.916 \mathrm{x} \\
\mathrm{Q}^{1.7153}\end{array}$ & 0.692 & 1258.143 & 167 & 148 & 58.1 & 41.9 & 1.34 \\
\hline Kocaçay & 2308 & 314 & 25 & $1952-1996$ & 1971-1999 & $\begin{array}{c}\mathrm{Q}_{\mathrm{s}}=3.4566 \mathrm{x} \\
\mathrm{Q}^{1.373}\end{array}$ & 0.863 & 1065.53 & 115 & 46 & 48.3 & 51.7 & 1.31 \\
\hline Simav & 4944 & 316 & 32 & $1952-1996$ & 1964-1999 & $\begin{array}{c}\mathrm{Q}_{\mathrm{s}}=1.2804 \mathrm{x} \\
\mathrm{Q}^{1.6197}\end{array}$ & 0.770 & 372.369 & 112 & 94 & 51.5 & 48.5 & 1.32 \\
\hline Kocadere & 4424 & 317 & 02 & 1964-1996 & 1979-1999 & $\begin{array}{c}\mathrm{Q}_{\mathrm{s}}=2.643 \mathrm{x} \\
\mathrm{Q}^{1.2452}\end{array}$ & 0.727 & 464.950 & 115 & 84 & 34.5 & 65.5 & 1.26 \\
\hline
\end{tabular}


Table 5: Major element composition of modern and pre-modern sediments of Lake Manyas. Results for M.6 and M.16 bottom surface samples are from Suliman (1998).

\begin{tabular}{|l|l|l|l|l|l|}
\hline Elements in \% & $\begin{array}{l}\text { St II, 350-352 } \\
\text { cm }\end{array}$ & $\begin{array}{l}\text { St II, 400-401 } \\
\text { cm }\end{array}$ & $\begin{array}{l}\text { St II, 439-440 } \\
\text { cm }\end{array}$ & $\begin{array}{l}\text { M.6 (=St II) } \\
\text { surface }\end{array}$ & $\begin{array}{l}\text { M.16 (=St III) } \\
\text { surface }\end{array}$ \\
\hline $\mathrm{Na}_{2} \mathrm{O}$ & 1.09 & 0.98 & 0.90 & 0.17 & 0.15 \\
\hline $\mathrm{MgO}$ & 3.12 & 3.10 & 2.91 & 2.19 & 2.19 \\
\hline $\mathrm{Al}_{2} \mathrm{O}_{3}$ & 20.79 & 21.88 & 22.36 & 19.57 & 20.07 \\
\hline $\mathrm{SiO}_{2}$ & 58.45 & 58.80 & 60.39 & 51.32 & 52.95 \\
\hline $\mathrm{CaO}$ & 4.14 & 3.00 & 1.82 & 0.19 & 0.14 \\
\hline $\mathrm{TiO}_{2}$ & 1.03 & 0.95 & 0.96 & 0.68 & 0.75 \\
\hline $\mathrm{MnO}_{\mathrm{Fe}} \mathrm{O}_{3}$ & 0.14 & 0.13 & 0.10 & 0.74 & 0.64 \\
\hline $\mathrm{K}_{2} \mathrm{O}$ & 9.00 & 9.07 & 8.44 & 8.33 & 8.16 \\
\hline Loss-on- ignition & - & 1.96 & 1.94 & 2.01 & 2.19 \\
\hline total & 99.64 & - & - & 13.85 & 12.75 \\
\hline
\end{tabular}

Table 6. $\mathrm{C}^{14}$ ages and sedimentation rates in the southern Marmara region. a- from Cagatay et al. (2000), b- from Bottema et al. (2001), c derived by ${ }^{210} \mathrm{~Pb}$ and ${ }^{137} \mathrm{Cs}$,

\begin{tabular}{llll}
\hline Site, location, water depth & core depth, $\mathrm{m}$ & Age, uncal. yr BP & sedimentation rates, cm.yr
\end{tabular}

13 , southern shelf, $-70 \mathrm{~m}$ 22 , depression on shelf, $-110 \mathrm{~m}$ 88 , southern shelf, $-49 \mathrm{~m}$ GM-2, southern shelf, $-37 \mathrm{~m}$ GM-6, southern shelf, $-99 \mathrm{~m}$, GM-7, margin, $-370 \mathrm{~m}$, GM-7, margin, $-370 \mathrm{~m}$, LM, Lake Manyas, onshore LA, Lake Ulubat, south shore (no bold)

St-3, Lake Manyas

St-3, Lake Manyas St-3, Lake Manyas

$\begin{array}{cc}1.82-1.84 & 3540+190 /-185 \\ 1.92-1.94 & 4370+200 /-195 \\ 0.92-0.94 & 2550 \pm 65 \\ 1.72-1.74 & 3640 \pm 175 \\ 2.17-2.19 & 11,805+485 /-455 \\ 0.99-101 & 7735 \pm 125 \\ 2.22-2.24 & 12,955+350 /-335 \\ 2.80 & 3200 \\ \text { d) } 6.89-6.90\end{array}$

0.25

4.09

10.80 $\begin{array}{cc}0.052 & \text { (a) } \\ 0.044 & \text { (a) } \\ 0.036 & \text { (a) } \\ 0.047 & \text { (a) } \\ 0.018 & \text { (a) } \\ 0.013 & \text { (a) } \\ 0.023 & \text { (a) } \\ 0.08 & \text { (b) }\end{array}$

0.21 (b)

0.44 (c)

0.27

0.26 



\section{Figure captions}

Fig. 1: Location (A) and main streams of the southern drainage catchment of the Marmara Sea (B)

Note that Lake Manyas area is part of the Susurluk drainage basin.

Fig. 2:Morphology and bathymetry of Lakes Manyas and Ulubat. Depths are in $\mathrm{cm}$. Black dots are core stations.

Fig. 3: Quaternary evolution of the drainage pattern in the Karacabey-Manyas depression: 1) Early-Mid Pleistocene, 2) Late Pleistocene, 3) Early Holocene, 4) Mid-Late Holocene (from Emre et al, 1997b). B Bursa city, K Karacabey town, LM Lake Manyas, LU Lake Ulubat, $\mathbf{M}$ town of Manyas, $\mathbf{R}$ river

Fig. 4: Distribution of precipitation in the Susurluk basin

Fig.5: Annual fluctuations of water levels of Lake Manyas between 1997-2002. Compare monthly changes with Tables 1 and 3.

Fig. 6: Change of grain size in sediment of Lake Manyas along the sequence at the site Station 3. Letters at right are the core numbers.

Fig. 7: Sand-size micronodules from lake Manyas sediment (A-D). They are formed by alternations of siderite (darker zones) and illite (light zones) bundles.

Fig. 8: Ages and sedimentation rates in the lacustrine sequence of Lake Manyas. The time-limit between pollen zones 1 and 2 is obtained by intrapolation. Palaeoenvironment reconstruction (at the left) depends on palynology (Leroy et al., 2002).

Fig. 9: Holocene sedimentation rates in the southern Marmara region (horizontal axis in uncal. radiocarbon dates BP). A) Lake Manyas, B) Southern shelf of Marmara Sea. See Fig. 1 and table 6 for core sites and depths.The sapropel formation time is also from original data of Çağatay et al. (2000), C) Comparison of deposition in the lake and shelf environment. Note the broad parallelism with a slight shift between 4400-2000 uncal. years BP.

Fig. 10: A holistic model for sedimentation-denudation/erosion in the Susurluk basin. 